Vol. No. 1, Issue No. 1, December, 2017, 21-42

Copyright $\odot$ IIUM Press

eISSN 2600-8432

\title{
Watt's View on Muslim Heritage in The Study of Other Religions: A Critical Analysis
}

\author{
Wan Mohd Fazrul Azdi Wan Razali* \\ Mohd Rosmizi Abd Rahman** \\ Jaffary Awang ***
}

\begin{abstract}
:
This paper examines a writing of the late William Montgomery Watt's (1909-2006) monumental work entitled Muslim-Christian Encounters: Perceptions and Misperceptions that is related to the legacy of study of religions. The authors emphasize on Watt's important claim that due to Muslims' tradition of Islamic self-sufficiency or showing no interest in studying doctrines of other religions, has led to the dearth of literatures in the field. This study employed a qualitative methodology in which the textual analysis approach was applied on Watt's writing. The findings indicate that there are seven examples provided by Watt to strengthen his notion of Islamic self-sufficiency, each of whom has methodological flaw and opens room for criticism and improvement.
\end{abstract}

Keywords: Muslim, the study of other religions, purposiveness and non-purposiveness, William Montgomery Watt and Islamic Self-Sufficiency.

\section{Introduction}

According to the late Eric J. Sharpe ${ }^{1}\left(1933\right.$ - 2000) and Ninian Smart ${ }^{2}$ (1927-2001), the history of the study of religions has begun as early as man initially questioned on religion in an attempt to understand its

\footnotetext{
* Dr. Wan Mohd Fazrul Azdi Wan Razali, is Lecturer, Department of Akidah and Religion Studies Program, Universiti Sains Islam Malaysia. Email: wmfazrul26@yahoo.com

** Dr. Mohd Rosmizi Abd Rahman, is Senior Lecturer, Department of Akidah and Religion Studies Program, Universiti Sains Islam Malaysia

Universiti Sains Islam Malaysia. Email: rosmizi@usim.edu.my

*** Dr. Jaffary Awang is Associate Professor, Department of Theology and Philosophy, Universiti Kebangsaan Malaysia. Email: jaffary@ukm.edu.my

${ }^{1}$ Eric John Sharpe, Comparative Religion: A History (Illinois: Open Court. 1986), 1-2.

2 Smart, N. "Study of Religion", Encyclopedia Britannica. Retrieved September 18, 2006, via Encyclopedia Britannica 2006 Ultimate Reference Suite DVD.
} 
various aspects, especially through the use of other intellectual disciplines. Whilst, Jacques Waardenburg (born 1930) suggests that the study of religion "includes all studies concerned with religious data, their observation, ascertainment, description, explanation, analysis, understanding, [and] interpretation."1

In brief, this questioning on religious issues can be divided into two main forms, specifically insider's or outsider's question on religious issues. Insider's study of religions is an attempt to understand the various aspects of one's own religion and this is most common form of study from the outsider's study of religions. The insider's study of religion mainly undertaken within each religion for the purpose of maintaining religious understanding among its believers and practitioners. Whereas the outsider's study of religions is vice-versa or an attempt to understand the various aspects of other people's religion. ${ }^{2}$ It has been a great controversy in the study of religions ever since, to debate on this issue of the inside or outside view of religions. ${ }^{3}$ In addition, it is also debatable, whether a religion promotes the study of other religions. Could there be any reasons for a particular religion to promote or to prohibit the study of the other religions from its own?

In the year 1991, William Montgomery Watt (1909-2006) published his monumental work titled: Muslim-Christian Encounters: Perceptions and Misperceptions. In a section of this work titled Islamic Self-Sufficiency, Watt remarks an important claim that Muslims have shown no interest in studying doctrines of other religions. Nevertheless, many international scholars; be them from the east and west, Muslims or non-Muslims; recognize Muslim scholarship in the study of other religions. In sum, comparative study of religions is regarded as one of the great contributions of Muslim's civilization to mankind's intellectual progress. This article unravels this issue and analyzes this claim by listing samples of Muslim works in the comparative religion and

${ }^{1}$ Carl Olson, Theory and Method in the Study of Religion: A Selection of Critical Readings. (USA: Cengage Learning, 2003), 5.

${ }^{2}$ McCutcheon, Russell. T. The Insider/Outsider Problem in the Study of Religion: A Reader. (London: Cassell. 1999).

${ }^{3}$ Gardiner, Mark Q. and Engler, Steven. Semantic Holism and the Insider-Outsider problem. Religious Studies, 48, 2012, pp. 239-255; Pembroke, Neil, Outsiders and Insiders Personal Reflections on Methodology in Studies in Religion at the University of Queensland, 1986-2010. Crossroads. 5 (2) (2011). 123-126; Kim Knott, "Inside, Outside and the Space in-between: Territories and Boundaries in the Study of Religion," Temenos: Nordic Journal of Comparative Religion. 44 (1). 2008. 41-66. 
proposing an alternative categorization or taxonomy with regards to Muslim heritage in the study of other religions.

\section{Watt and his claim of Islamic Self-Sufficiency}

Watt who was an Emeritus Professor of Arabic and Islamic Studies at the University of Edinburgh, Scotland, was called the 'Last Orientalist' by the Muslim Press. ${ }^{1} \mathrm{He}$ was highly celebrated in the field of study of the Orient; particularly in the Islamic studies due to his prolific writings and lectures on themes such as Islamic creed, Prophet Muhammad PBUH, Islamic history, al-Ghazālī (d. 1111) and Christian-Muslim relations. His early interests on Arab and Islam were ignited from his religious discussions and debates with K.A. Mannan, his Pakistani Ahmadi neighbour in 1930's. ${ }^{2}$ Watt completed his Ph.D. dissertation on the concept of free will and predestination in early Islam under the supervision of Richard Bell (1876-1952), a renowned Western scholar in the study of Qur'an and its translation. In 1964, he accepted the chair of Professor of Arabic and Islamic Studies of Edinburgh University from which he retired in $1979 .^{3}$

The Islamic influence on Watt's understanding of Christianity could be seen in his discussion of the doctrine of Trinity and the 99 names of Allah (al-Asmā' al-husnāa). These beautiful names of Allah were not only understood as attributes, but also 'persona' (in Latin means mask or face) for God. "He formulated the view that a truer

${ }^{1}$ Bashir Maan and Alastair McIntosh. 2000. "The Whole House of Islam, and we Christians with them..." An interview with the "Last Orientalist." The Coracle, the Iona Community. 3:51. 8.

${ }^{2}$ Holloway, Richard. 2006. William Montgomery Watt: A Christian scholar in search of Islamic understanding.The Guardian UK. 8 September, 2015. <http://www.theguardian.com/news/2006/nov/14/ guardian obituaries highereducation>

${ }^{3}$ He held the post of Assistant Lecturer in Moral Philosophy at Edinburgh from 19341938, Lecturer in ancient Philosophy 1946-1947, and then successively Senior Lecturer and Reader in Arabic from 1947-1967. He had authored more than 30 books, which are now mostly used as references in Islamic and Orientalism studies e.g.: Free Will and Predestination in Early Islam (1948), The faith and practice of al-Ghazālī (1953), Muhammad at Mecca (1953), Muhammad at Medina (1956), Muhammad: Prophet and Statesman (1961), Islamic Philosophy and Theology (1987), Islamic Political Thought (1998) and Islam: A Short History (1999) as to name a few. Alfred, Charlotte. 2007. Obituary | William Montgomery Watt. Edinburgh Middle East Report, 8 September $2015 . \quad<\mathrm{http}$ ://emeronline.blogspot.my/2007/01/obituary-william-montgomerywatt.html> 
interpretation of the Trinity would not signify that God comprises three individuals. For him, the Trinity represents three different 'faces' of the one and the same God." 1 The Department of Islamic and Middle-Eastern Studies, Edinburgh University agrees that "Edinburgh's present international reputation in the field of Islamic Studies is inseparable from the name of William Montgomery Watt."2

Muslim-Christian Encounters: Perception and Misperceptions shows that throughout history, Muslim-Christian relations and encounters have been troubled by a number of myths and misperceptions, many of which exist until present day. ${ }^{3}$ Whilst, Islamic Self-sufficiency is a section included under chapter 3 entitled 'The Elaboration of Qur'anic Perceptions,' which covered four pages from page forty-one to page forty-four. The title Islamic Self-sufficiency used by Watt to signify the position of Islam vis-à-vis other religions, where "Islam possesses in essentials all the religious and moral truth required by the whole human race from now until the end of time. Hence in the religious and moral sphere Islam has nothing to learn from any other system of thought." 4

At first, there was nothing wrong with Watt's claim of Islamic Self-Sufficiency. For such claim was in line with the fundamental teachings of Islam, where Islam has nothing to learn or to source from any other systems of thought to understand Islam. In Islam, Allah the Most High was the primary source of knowledge to understand Islam. Due to that, it was unanimously agreed by the renowned scholars of Islam that the sources of knowledge to understand Islam are al-Qur'ān, al-Sunnah and the intellectual reasoning or Ijtihād by the reputable Muslim scholars. ${ }^{5}$ Furthermore, this attribute of Islamic self-sufficiency

\footnotetext{
${ }^{1}$ Carol Hillenbrand,(2006). Professor W. Montgomery Watt: Son of the Presbyterian manse and Episcopal priest who became a leading interpreter of Islam. The Independent UK. 8 September 2015. <http://www.independent.co.uk/news/ obituaries/professor-w-montgomery- watt- 423394.html>

${ }^{2}$ Watt died on October 24, 2006 at the age of 97 and survived by a wife, five children and grandchildren.Alfred, Charlotte. 2007. Obituary | William Montgomery Watt. Edinburgh Middle East Report. 8 September 2015. <http://emeronline.blogspot.my/2007/01/obituary-william-montgomery-watt.html>.

3 William Montgomery Watt, Muslim-Christian Encounters: Perceptions and Misperceptions, (London and New York: Routledge. 1991).

${ }^{4}$ Watt, Muslim-Christian Encounters, 41.

5 Taha Jabir Al-Alwani, Usul al-Fiqh al-Islami: Source Methodology in Islamic Jurisprudence. (Virginia: The International Institute of Islamic Thought, 1990),7-9; Muhammad Abd. Rauf, The Muslim Mind: Foundation and Early Manifestation.
} 
also synchronizes with the understanding of Islamic religious sovereignty in promoting its own ideals and practices. Or to paraphrase, what is a religion if it is not sovereign? Evidently, Allah the Most High says in Sürah al-Nisā' 4: verse 59, which means: O you who believe! obey Allah and obey the Messenger and those in authority from among you; then if you quarrel about anything, refer it to Allah and the Messenger, if you believe in Allah and the last day; this is better and very good in the end.

Nevertheless, when Watt continues his elaboration on this claim of Islamic Self-Sufficiency, he notes as follows:

The result of this general attitude has been that Muslim ulema, the official religious scholars of Islam, have constantly tried to prevent ordinary Muslims from gaining any knowledge of false or heretical doctrines. When Muslim scholars wanted to write books about the Muslim sects, it was necessary for them, before they did so, to justify their enterprise by claiming that they were explaining and illustrating a statement of Muhammad's about the seventy-three sects of Islam. In a similar way Muslims have shown no interest in studying doctrines of other religions. There were indeed one or two exceptions to this in medieval times, but it is only in last couple of decades that Islamic universities have begun to study comparative religion."1

Here, it is clear that Watt speculated his claim of Islamic selfsufficiency to become a reason for the disinterest and disregard among Muslims in studying other religions. At first glance, the logic sounded acceptable for Watt to speculate as such. For Islam was self-sufficient therefore Islam disfavoured and prohibited the study of other religions. In other words, why would a religion, which does not need to source from other religions to understand itself promotes the study of other religions such as Christianity, Judaism, Zoroastrianism, Sabeanism, Magianism and many more? Notwithstanding of his claim, Watt continued his statement of Muslim disinterest and prevention from studying other religion by saying that there were exception of one or two works of comparative religions in the medieval times. And this is followed by Watt's remark that the beginning of the study of

(Kuala Lumpur: Dewan Bahasa dan Pustaka,1991); Muḥammad al-Ghazālī, Laysa Min al-Islām. (Cairo: Dār al-Shurūq, 1998), 56 - 65.

${ }^{1}$ Watt, Muslim-Christian Encounters, 42. 
comparative religions in the Islamic universities was only in the last couple decades.

Watt also explains seven supporting events in the Islamic history to establish his claim of Islamic self-sufficiency that resorted to the disinterest of comparative religions by Muslims. They are:

1. Edward Gibbon's (1737-1794) history of the Roman Empire, where it was cited that during Alexandria conquest, Umar had ordered for the books in the Alexandria Library, which contradict the Qur'an to be destroyed. ${ }^{1}$

2. Imām Aḥmad ibn Hạbal's (780-855) critique of Imām al-Hārith al-Muhāsibī's (781-857) book on refuting Muctazilism. Aḥmad criticized the full-length description on $\mathrm{Mu}^{\mathrm{c}}$ tazilism doctrines given by al-Muhāāibī prior to his refute, where Ahmad was afraid that someone who read al-Muhāsibī's book might accept the false doctrines after reading only the particular part of $\mathrm{Mu}^{\mathrm{c}}$ tazilism doctrines without knowing the refutation, which came later. $^{2}$

3. Salman Rushdie's (b. 1947-) The Satanic Verses (1988) book ban and burning in the Islamic countries. ${ }^{3}$

4. Rasulullah's PBUH prohibition on 'Umar (d. 644) and other companions from being amazed with the book of the People of the Book as narrated by al-Bukhārī (810-870). ${ }^{4}$

5. Ibn Abbās' (d. 687) prohibition on the people to ask religious matters from the People of the Book, which was also narrated by al-Bukhārī. ${ }^{5}$

6. Gradual rejection of the Isrā'îliyyāt in the hadīths of the Prophet PBUH as narrated by al-Bukhārī and Muslim (815-875), which was presumed by Watt. ${ }^{6}$

7. Rashīd Riḍā's (1865-1935) attack of some stories reported by $\mathrm{Ka}^{\mathrm{c}} \mathrm{b}$ al-Aḥbār (d. 652) and Wahb ibn Munabbih (d. 738), even though authenticated by al-Bukhārī. ${ }^{7}$

\footnotetext{
${ }^{1}$ Ibid.

${ }^{2}$ Ibid., 41-42.

${ }^{3}$ Ibid., 42.

${ }^{4}$ Ibid., Muslim-Christian Encounters, 43.

${ }^{5}$ Ibid.

${ }^{6}$ Ibid

${ }^{7}$ Ibid., 43-44.
} 
If these seven examples are to be understood from their literal words and meanings, they project a negative image of Islam which disfavours and dislikes any encounter with false doctrines and other religions. In fact, these seven examples emerged in the Islamic history for their specific reasons and needs, which is unjust to be generalized or understood literally and taken as evidences to show that Muslims have shown no interest in studying the doctrines of other religions. After examining these seven examples and Watt's claim in this section on Islamic Self-Sufficiency, his remarks on the Muslims have shown no interest in studying doctrines of other religions are answered from two main points, namely first, his sources and secondly, his ideas.

For the first point, Watt uses a number of classical and modern sources for these seven examples, namely: Chapter 51 of Edward Gibbon's The History of the Decline and Fall of the Roman Empire, ${ }^{1}$ alGhazālī's al-Munqidh Min al-Dalāl, ${ }^{2}$ Saḥīh al-Bukhārī, Sahīh Muslim, Brill's Encyclopedia of Islam and Juynboll's (1935-2010) The Authenticity of the Tradition Literature: Discussions on Modern Egypt. Evidently, these sources for his claim are not actually regarded as final sources to understand this issue at hand. Furthermore, these sources do not present their contents towards the same refutable conclusion as claimed by Watt. For instance, if one refers directly to two out of seven sources used by Watt, namely Gibbon's The History of the Decline and Fall of the Roman Empire and al-Ghazālī's al-Munqidh Min al-Dalāl, one finds that these authors had commented on their narratives differently from the path taken by Watt.

Gibbon remarks his denial of the narrative on 'Umar's order for the books in the Alexandria Library to be destroyed, where Gibbon commented: "the rigid sentence of Omar is repugnant to the sound and orthodox precepts of the Mahometan casuists: they expressly declare, that the religious books of the Jews and Christians, which are acquired by the right of war, should never be committed to the flames; and that the works of profane science, historians or poets, physicians or philosopher's, may be lawfully applied to the use of the faithful." 3 Whilst, al-Ghazālī's remark on the position taken by Imām Aḥmad ibn

1 Edward Gibbon, The History of the Decline and Fall of the Roman Empire. (Philadelphia: William Y. Birch and Abraham Small, 1805) 6: 366-367.

${ }^{2}$ Abū Hạamid al-Ghazālī, al-Munqidh Min al-Dalal. (Beirut: Dar al-Andalus, n.d), 118119; William Montgomery Watt, The Faith and Practice of al-Ghazali, (London: George Allen and Unwin Ltd.1952) 44-45.

${ }^{3}$ Gibbon, 367. 
Hanbal is as follows:

"What is said by Ahmad is right, but it is in the case of false doctrine, which is not widely and generally known. Where such false doctrine is widely known (such as Muctazilism), it must be refuted by firstly mentioning of its false doctrines."

Whilst for the third example, the banning and burning of Salman Rushdie's The Satanic Verses was actually a political repercussive act shown by the Muslim countries to firmly uphold Islamic teachings. Furthermore, Salman Rushdie's was not actually a book of comparative religion, but a blasphemous and heretical belles lettres (literature) that projected a perverted view of Islam. Whereas, for examples number four to seven, Watt was supposed to use Muslims' authorized texts on shurūh al-hadìth (elaboration of hadith) for al-Bukhārī and Muslim, for example Ibn Rajab's (1335-1393) Fath al-Bārī and Ibn Hajar al-'Asqalānī's (1372-1449) Fath al-Bārī, or al-Nawāwī’s (1233-1277) and al-Suyūṭ̂̀'s (1445-1505) elaboration on Muslim's ḥadīth. Elaborations on the hadīths are very important to ensure that the contextual meanings of the hadiths could be grasped and to avoid from misconstruing the real idea from the riwāyāt or narratives on Isrā 'illiyyāt. Many scholars from the earliest time up until today had elaborated the three Islamic rulings on the use of Isrā' illiyyāt, ${ }^{2}$ where it was a wishful thinking by Watt to perceive all these hadiths to convey a meaning of gradual rejection of the Isrā 'illiyyāt in the Muslim scholarship.

Secondly, when it comes to answering Watt's ideas for his claim of the Muslims have shown no interest in studying doctrines of other religions, Watt was not supposed to speculate that Islamic self-

وما ذكره أحمد بن حنبل حق، ولكن في شبهة لم تنتشر ولم تشتهر فأما إذا انتشرت، فالجواب عنها واجب ولا يمكن الجواب عنها إلا بعد 1 إلمابة Al-Ghazālīi, 119.

${ }^{2}$ Muhammad ibn Idrīs al-Shāficīi, al-Risālah (Beirut: Dār al-Kutub al-'lmiyyah, n.d), 397-400; Ibn Taimiyyah, Muqaddimah Fi Ușūl al-Tafsīr. (Beirūt: Dār Ibn Hazm,1994), 90-91; Ibn Kathīr, Tafsìr Al-Qur'ān Al- ${ }^{c}$ Azìm. Cairo: Muassasah Qurțūbah,2000), 1:9-

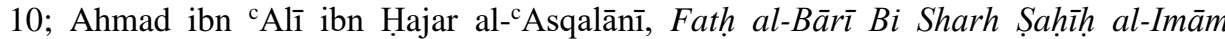
Muhammad ibn Ismācill al-Bukhārī. (Riyadh: n.pl. 2001), 6: 575; Muḥammad Husayn al-Dhahabī, Al-Isrā'ìliyyāt Fì al-Tafsìr Wa al-Hadìth,(Cairo: Maktabah Wahbah, 1990),41-52; Ismail Albayrak, Qur'anic Narrative and Israiliyyat in Western Scholarship and in Classical Exegesis. Unpublished Doctor of Philosophy thesis. University of Leeds. 2000, 116-121; Șalāh c ${ }^{c} A b d$ al-Fattāḥ al-Khālidī, Maca Qașaș alSābiqīn F̄̄ al-Qur'ān, (Damascus: Dār al-Qalam,2007),43-55. 
sufficiency means that there is no Muslim scholarship in the study of other religions. This is due to the historical facts of Muslim contributions to this particular discipline of study, which not only begun in the last couple of decades as in Watt's claim, but from the earliest days of Islam. His idea was supposed to be supported and justified with arguments from the texts and writings in the discipline of comparative religions, instead of historical, sufism or hadìths sources as aforementioned. Watt did use Jacques Waardenburg's 1979 article entitled 'World Religions as Seen in the Light of Islam,' which was published as a festschrift (a tribute writing) for Watt, which listed only one or two works of Muslim contributions in the comparative study of religions. ${ }^{1}$ However in 1999, Jacques Waardenburg published an edited work on the Muslim Perceptions of Other Religions: A Historical Survey with Oxford University Press (OUP). In this latest work, he listed more than 20 works of medieval Muslim (650-1500 CE) contributions in the comparative study of religions, including the missing works of Ibn alMuqaffa $^{c}$ (d. ca. 756), al-Warrāq (d. 861) and Abū Muḥammad al-Hasan al-Nawbakhtī (d. 912). ${ }^{2}$ With this note, it is unacceptable for anyone to claim that Islamic self-sufficiency entails Muslims disinterest of the study of other religions. In the next three subsequent parts, this article elaborates Muslim contributions in the comparative study of religions, which are not only restricted qua purposive religious study, but also through the study of tafsir , hadìth, fiqh, 'aqìdah and many more nonpurposive treatises.

What went wrong in Watt's claim was that he had mistakenly linked between the (1) first premise of Islamic self-sufficiency, to the (2) second premise of the official religious scholars of Islam who have constantly tried to prevent ordinary Muslims from gaining any knowledge of false or heretical doctrines, to the (3) conclusion of Muslim disinterest in the comparative study of religion. This is evident at the end of the section, where Watt notes as follows:

Throughout the centuries the ulema have used their authority to prevent the dissemination of all heretical or non-Islamic views, and indeed of whatever deviated from their own teaching and from the self-image as they conceived it. The suppression or squeezing out of undesirable views has been carried out by

\footnotetext{
${ }^{1}$ Watt, Muslim-Christian Encounters, 154.

${ }^{2}$ Waardenburg, Jacques. (ed.) Muslim Perceptions of Other Religions: A Historical Survey, (Oxford: Oxford University Press, 1999), 18-59.
} 
methods not unlike those of western totalitarianism. In some Islamic countries at the present time it is virtually impossible for Muslim intellectuals to publish anything at variance with the dominant fundamentalism or traditionalism. ${ }^{1}$

Watt is actually supposed to differentiate and distinguish between both contexts in the Muslim scholarship, namely first, the prevention of dissemination of heretical or non-Islamic views and secondly, the academic or intellectual study of other religions. Prevention or prohibition of widespread of heretical or non-Islamic views by the scholars of Islam are best understood as sadd al-dharā' $i^{c}$ or blocking the bad means, especially among the public and ordinary Muslims. This is beautifully described by al-Ghazālī:2 "the same as a child is protected from the riverside, fear for him or her from drowning in the river." Nevertheless, this does not mean that the study of other religions is totally prohibited. Al-Isfarāyīn̄i (d. 1028) exemplifies this in a poetical:" "I know (or learn) the wrong teachings not for the sake of it (or to apply it) but for protection, one who does not know (or learn) the wrong teachings might just involve with it." In addition, to study other religions is also to get to know others faith and religious practices, which also culminated as cultures and traditions. In Sürah al-Hujurāt, 49: verse 13, Allah the Most High says: O you men! surely We have created you of a male and a female, and made you tribes and families that you may know each other; surely the most honorable of you with Allah is the one among you most careful (of his duty); surely Allah is Knowing, Aware.

In a sense, it seems that Watt used circumstantial evidences ${ }^{4}$ here to conclude that Islamic self-sufficiency, which disfavours the study of other religions merely from the previous seven justifications. What Watt should really be doing was to properly discern and deeply investigate the raison d'etre of these seven examples and to be compared with the other stands in the Muslim scholarship. It is of utmost pertinence for any

\footnotetext{
${ }^{1}$ Watt, Muslim-Christian Encounters, 44.

2 ما يصان الصبي عن شاطىء النهر خيفة عليه من الوقوع في النهر . Abū Hāāmid Al-Ghazālī, Ihyā' ${ }^{c}$ Ulūm al-Dìn. (Beirut: Dār al-Macrifah.1982), 1: 22.

عرفت الشر لا للشر ولكن لتوقية، ومن لم يعرف الشر يقع فيه 3 Abū al-Muẓaffar Al-Isfarāyīn̄i, alTabșìr Fī al-Dìn. (Cairo: al-Maktabah al-Azhariyyah Li al-Turāth, 2010), 14.

4 Evidence not bearing directly on the fact in dispute but on various attendant circumstances from which the judge or jury might infer the occurrence of the fact in dispute. Look: The American Heritage Dictionary of English Language, (Boston: Houghton Mifflin, 1992) ,1444.
} 
scholars to avoid from making any sweeping judgments, which could result to the fallacy of hasty generalization and weak conclusion.

Nevertheless, this does not mean that the intellectual condition of the Muslim scholarship in the comparative study of religions is always perfect and beyond criticism. As previously mentioned, this article purports to answer Watt's claim that Islamic self-sufficiency leads to Muslims have shown no interest in studying the doctrines of other religions. It could be stressed here that the study of other religions in Islam began simultaneously with the general development of Muslim scholarship. These important points on the development and works of Muslim scholarship in the comparative study of religions are further justified and explored in the next discussion.

\section{Scholarly Acknowledgments on the Muslim scholarship in the Comparative Study of Religions}

Many international scholars; be them from the east and west, Muslims or non-Muslims; recognized Muslim scholarship in the comparative study of religions or the study of other religions. According to the late Ahmad Shalaby (1915-2000), the Muslims were the earliest to contribute the intellectual development in this discipline for many other non-Islamic religions denied and condemned the existence of other religions. ${ }^{1}$

It is worth mentioning here among the early Muslim scholars in this discipline were al-Ḥassan b. Mūsā al-Nawbakhtī (d. 819) through his al-Arā' Wa al-Diyānāt, al-Mas'ūdī (d. 956) through his al-Diyānāt, al-Musabbih̄ī (d. 1030) Dark al-Bughiyyah F̄̄ Wașf al-Adyān Wa al'Ibādāt, Abū Manșūr al-Baghdādī’s (d. 1037) al-Milal Wa al-Nihal, Ibn Hazm's (d. 1064) al-Fișal Fĩ al-Milal Wa al-Ahwā' Wa al-Nihal, alShahrastān̄̄'s (d. 1153) al-Milal Wa al-Nihal and al-Bīrūnī’s (d. 1048) Tahqūq Mā Li al-Hind Min Maqūlah Maqbūlah Fì al- ${ }^{c} A q l$ Aw Mardhülah. ${ }^{2}$ Unfortunately, many of these early works were only noted in the pages of historical books of manāqib, țabaqāt and tāri kh; whereby only a few of them managed to survive to the present day for academic reference and analysis.

The late Shalaby therefore urges the present Muslims to continue

\footnotetext{
${ }^{1}$ Aḥmad Shalaby, Muqāranah al-Adyān: Al-Yahüdiyyah. (Cairo: Maktabah Al-Nahụah Al-Mișriyyah,1988), 24.

${ }^{2}$ Ibid. $27-28$
} 
this academic pursuit from the past. ${ }^{1}$ This sense of urgency has also been shared by the present Muslim scholars of study of religions, such as Muhammad ${ }^{\mathrm{c}} \mathrm{Abd}$ Allāh al-Sharqāwī. He also acknowledges that Muslim scholarship in the study of other religions, in comparison to other nations and religions, with two special attributes: first, this study being independent as a discipline of knowledge and second, the results of findings are trustworthy and reliable. ${ }^{2}$

Such recognition also came from many non-Muslim scholars. For instance, H.U. Weitbrecht Stanton (1851-1937) acknowledges, "no other scripture in the world teaches comparative religion as the Qur'ān."3 Whilst, Adam Mez (1869-1917) in his The Renaissance of Islam highlights that the spirit of toleration that was missing in the Medieval Europe, could only be found among the Muslims due to the Muslim comparative study of religions. He states: "this toleration found expression in Islam in the creation of the science of Comparative Religion and its enthusiastic cultivation." "In the same gesture, the late Franz Rosenthal (1914-2003) remarks, "the comparative study of religions has been rightly acclaimed as one of the great contributions of Muslim civilization to mankind's intellectual progress." 5

In sum, comparative study of religions is regarded as one of the great contributions of Muslim's civilization to mankind's intellectual progress. This is due to the nature of this study, which recognizes and calls for the understanding of the pluralistic nature of human faith. The religion of God is one, but the religion of humankind is multiple in number. ${ }^{6}$ This recognition and calling for the understanding of the various kinds of human religions are enshrined in the Holy Qur'ān. Muslims learn this fact from the Quran and in the passage of time; many prominent religious scholars emerged as scholars of the study of other religions.

In order to illustrate the richness of Muslim scholarship in the

\footnotetext{
${ }^{1}$ Ibid, 24-36

${ }^{2}$ Muḥammad 'Abd Allāh al-Sharqāwī, Buḥūth F̄̄ Muqāranah al-Adyān (Cairo: Dār alFikr al- ${ }^{\mathrm{c}}$ Arabī, 2010), 16-18

3 Ghulam Haider Aasi. "The Qur'an and Other Religious Traditions." Hamdard Islamicus. vol. 9. no. 2.1989, 65.

${ }^{4}$ Adam Mez, The Renaissance of Islam. trans. by Salahuddin Khuda Bakhsh and Margoliouth, (D.S. Patna: Jubilee Printing \& Publishing House. 1937), 32, 209-210.

${ }^{5}$ Bruce Lawrence, Shahrastani on the Indian Religions, (Mouton: Mouton Co. 1976), 5 .

${ }^{6}$ Al-Qur'ān al-Karīm, Sūrah Āli 'Imrān, 3: 19, 85.
} 
study of other religions, the next discussion provides the categorization or taxonomy for the Muslim heritage in the study of other religions into two main categories, namely purposive and non-purposive. This categorization or taxonomy can guide the contemporary and future researchers to the great bulk of Muslim heritage in the study of other religions.

In this case, purposive category refers to the opuses and writings of the Muslim scholarship in the study of other religions, which their main and primary purpose of creation is for the study of religion/s. Conversely, non-purposive category refers to the rest and remaining works of the Muslim scholarship in the study of other religions, which the study of religion/s is undertaken not as the main reason of its creation. This categorization or taxonomy opens a new vista and paradigm at looking into the heritage of Muslim scholarship in the study of religions. ${ }^{1}$

\section{The Purposiveness of Muslim Scholarship in the Comparative Study of Religions}

The purposive sources here refer to the study of religions that are undertaken as the main or primary reason of their creation. They are also known as the focused, systematic and direct treatises on other religions. They are the works that are intentionally produced and devoted towards studying other religions. Muslim scholars already produced the purposive treatises on other religions since eighth or ninth century. However, this does not dispute the fact that Muslims already engaged in the study of other religions, in various situations and approaches, as early as in the time of Prophet Muhammad PBUH and his Companions. Some of these facts were already analyzed by Kamar Oniah in her Early

\footnotetext{
1 Further reference could be made to these journal articles: "Muslim Heritage In Religionswissenschaft: A Preliminary Study On The Purposiveness \& The NonPurposiveness Of Muslim Scholarship,” Journal of Islamic Studies and Culture, Vol. 2 Issue 2; September 2014, (USA: American Research Institute for Policy Development),2333-5904 (Print) 2333-5912 (online) and, "Muslim Heritage in Religionswissenschaft: A Preliminary Study On the Purposiveness \& the NonPurposiveness of Muslim Scholarship," Abqari: Journal of Islamic Social Sciences and Humanities. Vol. 4. 2014. (Nilai: Faculty of Leadership and Management, Islamic Science University of Malaysia) ISSN 2232-0431.
} 
Muslim Scholarship in Religionswissenschaft. ${ }^{1}$

Many approaches and styles are found in these purposive treatises. Some of them are descriptive in nature. Some are disputative, polemical and apologetic, which involve defending, refuting, and extensive criticism. While some others are analytical, involving serious studies of certain aspects of other religions. The treatises produced by Muslim scholars on other religions are not necessarily limited only to one particular style, for some of them employ different or mixed styles and approaches. This section discusses three main categories of purposive treatises: the descriptive, the disputative and the analytical treatises.

\section{The Descriptive}

The descriptive treatises of Muslim the study of other religions refer to such treatises, which are intentionally devoted and focused on other religions using descriptive method, devoid of refutation and criticism. The main objective of descriptive treatises is to offer general introduction and description about other religions. In the modern time, this kind of treatises can be found in the textbooks on comparative religions. Some of them offer introduction and description of various religions, while some other only focus on one particular religion. Among the best example for this first category is al-Shahrastānī's al-Milal Wa al-Nihal.

\section{The Disputative}

The disputative treatises of Muslim the study of other religions refer to such treatises, which are intentionally written for disputative purpose. These treatises are prepared either to defend Islamic teachings or to refute teachings of other religions. Hence, these kinds of treatises could be either apologetic or polemical in nature. In early Muslim the study of other religions, disputative treatises are obvious as the al-Radd (Refutation) treatises. These kinds of al-Radd treatises are intentionally devoted to refute or criticize some aspects of other religions. Among favoured aspects of other religions that are criticized and refuted by the early al-Radd treatises are theological (especially those related to the concept of God, particularly in Christianity) and scriptural aspects (e.g.,

\footnotetext{
${ }^{1}$ Kamar Oniah. Early Muslim Scholarship in Religionswissenschaft. (Kuala Lumpur: International Institute of Islamic Thought and Civilization, 2003)
} 
looking for discrepancies, contradiction and faulty data). ${ }^{1}$ Example for early Muslim disputative treatises are al-Radd ${ }^{c}$ ala al-Nașāra by Abu 'Īsā al-Warrāq (d. 994), Kitab al-Fișal F̄̄ al-Milal wa al-Ahwā' wa alNihal by Ibn Hazm, and al-Jawāb al-Ṣaḥ̄h Li Man Baddala al-Dīn alMasīh by Ibn Taimiyyah (d.1328).

\section{The Analytical}

The analytical treatises of Muslim the study of other religions refer to such treatises, which offer deep analysis of certain aspects of other religions. There will be refutation and debates in the analytical treatises, but they are academic in nature. In fact, the authors of the analytical treatises make serious and objective studies of relevant aspects of religions. Although there will be no extensive personal criticism as found in disputative treatises, some critical analysis based on objective and academic approach are still offered by certain analytical treatises. In some cases, the analytical treatises offer certain contributions, either on the theoretical or practical aspects of religions, or even on both of them. For example, there are cases where the analytical-purposive treatises offer suggestions for the improvement of certain specific aspects of religion/s. Some of them even able to formulate or systematize certain practical ways, theories, methodologies, or principles related to the study of other religions. Examples of the analytical-purposive works are too extensive to mention here. Most of academic journal articles, theses, or dissertations on different aspects of other religions fall under this category. The book entitled Christian Ethics by the late Ismail Raji alFaruqi (1921-1986) is among the best examples that offers various aspects of the analytical treatises mentioned here. ${ }^{2}$

\section{The Non-Purposiveness in the Comparative Study of Religions}

The non-purposive works of the Muslim scholarship in the study of other religions here refer to the study of religions, which is undertaken not as the main or primary reason of its creation. For instance, the main or primary reason for one's work could be for historical activity or sociological research. However, within one's records of historical activity or sociological research, one has included the study on religions within this specific work. Even though the reason

\footnotetext{
${ }^{1}$ Kamar Oniah. Early Muslim Scholarship, 25.

${ }^{2}$ Isma'il Raji Al-Faruqi,Christian Ethics: A Historical and Systematic Analysis of Its Dominant Ideas. (Kuala Lumpur: A.S. Nordeen, 1999)
} 
for the study on religions has not been in primacy, it is believed that many works and writings on Muslim scholarship in the study of other religions could be referred to within this second categorization or taxonomy. In brief, this is due to the many divisions of knowledge involved with the works in this second category, rather than the first one. As highlighted previously at the introduction, in the definition of study of religion by Smart and Waardenburg, the study of religion is an attempt to understand the various aspects of religion and includes all studies concerned with religious data. Hence, these religious aspects and data can be derived largely from the non-purposiveness of Muslim scholarship in the study of other religions.

The Non-purposiveness Categorization can be divided into eight groups: 1) Quranic Exegeses (Tafāsīr al-Qur'ān), 2) Hadīth Commentaries (Shurūh al-Ahādīth), 3) Historical Texts (al-Tawārīkh), 4) Islamic Jurisprudence (al-Fiqh), 5) Islamic Creed and Sects ('Aqidah wa Firaq), 6) Travelogues (al-Rihlāt), 7) Early Social Science, 8) Sufism (al-Tașawwuf). Many benefits could be gained from acknowledging this categorization or taxonomy for the Muslim heritage in the study of other religions. This is epistemologically evident from learning a wisdom from George Sarton (1884-1956), a renowned American philosopher and historian of science, where he exemplifies:

As every trained scholar knows (and superficial bibliographers forget), some of the best information on any subject is likely to be found in books devoted to large subjects or even to other subjects. For example, valuable information on Ibn Sina might be tucked in a general history of Islam or hidden in a medical journal or a metaphysical treatise. ${ }^{1}$

As a result, this categorization or taxonomy can assist one's reading towards deeper understanding on issues in Muslim scholarship in the study of other religions. Likewise, this categorization or taxonomy can also help one's research or study on the opinion of any Muslim scholars in the field of comparative religion. Accordingly, descriptions are made below on samples of treatises, which cover some aspects in the NonPurposiveness categorization or taxonomy of Muslim scholarship in the study of other religions.

${ }^{1}$ George Sarton, Introduction to the History of Science. (Florida: Robert E. Krieger Publishing Company Inc., 1975), 3: 9. 


\section{The Quranic Exegeses}

The Quranic exegeses (Tafāsīr al-Qur'ān) are one of the intensive and extensive sources on Muslim scholarship in the study of other religions. Al-Qur'ān is the most reliable source of knowledge in Islam. Thus, many prominent Muslim scholars refer to the Quran in explaining the teachings of other religions and describe their study of other religions in relation to the verses of the Quran. For example, the word $d \bar{i} n$ or religion derives 9 times in the Quran. Whilst, al-Yahüd (the Jew) 7 times, Hādu (Jews) 10 times, al-Nașārā (the Christians) 3 times, Ahl al-Kitāb (People of the Book) 31 times and al-Mushrikin (the polytheists) 24 times. These samples of terminologies are widely used in the study of religions. In this case, best reference could be made to the Tafāsìr al-Qur'ān to unveil its meanings and to understand the views of Muslim scholars upon it. These Tafāsīr al-Qur'ān include: al-Māturīdī's (853-944) Ta'wìlāt Ahl al-Sunnah, ${ }^{1}$ Fakhr al-Dīn al-Rāzì's (1149-1210) Mafātih al-Ghayb ${ }^{2}$ and Wahbah al-Zuhaylī's (1932-2015) al-Tafsìr alMunīr. ${ }^{3}$

\section{Hadīths Commentaries}

The same manner could also be found when it comes to the Hadīths commentaries (Shurūh al-Ahâadìth). If al-Qur'ān al-Karīm is regarded as the primary source in Islamic epistemology, hadith then is secondary. Muhammad (PBUH), the Prophet, being the receiver of God's verbatim is thus, the most authorized commentator of Islamic teachings vis-a-vis the other religions. The Messenger of Allah (PBUH) acts, words and standpoints on interreligious issues can be made intelligible with reference to the Hadiths commentaries. These treatises include al-Nawāwī's $a l-M i n h \bar{a} j^{4}$ and al- ${ }^{c}$ Asqalān̄̄'s Fath alBārī. ${ }^{5}$

\footnotetext{
${ }^{1}$ Abū Manșūr Muḥammad al-Māturīdī, Ta 'wīlāt Ahl al-Sunnah, (Beirut: Dār al-Kutub al-'Ilmiyyah, 2005)

${ }^{2}$ Fakhr al-Dīn al-Rāzī, al-Tafsīr al-Kabīr, (Beirut: Dār Iḥyā' al-Turāth al-'Arabī, 2001).

${ }^{3}$ Wahbah al-Zuhaylī, al-Tafsìr al-Munīr Fì al- ${ }^{c}$ Aqīdah Wa al-Sharī ${ }^{c}$ ah Wa al-Manhaj. (Damascus: Dār al-Fikr al-Mu'āșir, 1418H).

${ }^{4}$ Abū Zakariyyā Yaḥyā Ibn Sharaf al-Nawawī, Saḥ̄ḥ Muslim Bi Sharh al-Nawawī. (Beirut: Dār al-Kutub al-'Ilmiyyah, 1424H)

${ }^{5}$ Ibn Ḥajar al-Asqalānī, Fatḥ al-Bārī Sharḥ Șaḥ̄ḥ al-Bukhārī, (Riyadh: Dār al-Salām, 2000).
} 


\section{The Historical Texts}

The historical texts (Al-Tawärikh) are also included as one of the category in this taxonomy for the Muslim heritage in the study of other religions. This is evident by referring to some Muslim historical treatises, which also address the study of religion/s in their contents. However, this proposition should not be taken as an overgeneralization to all Muslim historical works. Some Muslim historians did include findings and discussions on the study of other religions in their writings, where they describe the history of other religions such as Judaism, Christianity, Sabeanism, Magianism and idol worshippers. Whilst, some perhaps do not see the need to do so. Examples of historical treatises for this taxonomy are: al-Mas ${ }^{\mathrm{u}} \overline{\mathrm{u}} \overline{\mathrm{i}}$ 's (d. 956) Murūj al-Dhahab Wa Ma ādin al-Jawhar, ${ }^{1}$ Ibn al-Athīr's (d. 1233) al-Kāmil Fi al-Tārīkh, ${ }^{2}$ Ibn Kathīr's (1301-1373) al-Bidāyah Wa al-Nihāyah ${ }^{3}$ and Ibn Khaldūn's (13321406) Diwān al-Mubtada' Wa al-Khabar Fi Tarīkh al- ${ }^{c}$ Arab Wa alBarbar Wa Man ${ }^{c} \bar{A}$ șarahum Min Dhawī al-Sha'n al-Akbar. ${ }^{4}$

\section{The Islamic Jurisprudence, The Islamic Creed and Sects, Travelouge, and Sufism.}

In Islamic Jurisprudence (al-Fiqh), views and findings on Muslim the study of other religions could be referred to in the issue of Muslims and non-Muslims relations in the al-Siyāsah al-Shar'iyyah or in the issue of Ahl al-Kitāb, which were touched by many fuqahà' (Islamic law jurists) from the earliest among the companions, prominent scholars of almadhähib al-fiqhiyyah to the present Muslim professors of Islamic fiqh. While in the Islamic Creed and Sects (Akidah and Firaq), reference could be made to treatises such as Abū $\mathrm{Nu}^{\mathrm{c}}$ aym al-Aṣbahānī's Dalā'il alNubuwwah ${ }^{5}$ and Fakhr al-Din al-Rāzī's I'tiqādāt Firaq al-Muslimīn $W a$ al-Mushrikin. ${ }^{6}$ The same also goes to the remaining divisions, such as

\footnotetext{
1 Abu al-Hasan ${ }^{\mathrm{c}} \mathrm{Al} \overline{1}$ ibn al-Husayn al-Mas' ${ }^{\mathrm{u}} \mathrm{d} \overline{1}$, Murūj al-Dhahab Wa Macādin alJawhar, (Beirut: al-Maktabah al- ${ }^{\mathrm{C}}$ Așriyyah, 2005).

${ }^{2}$ Muhammad Ibn Muhammad Ibn al-Athīr, al-Kāmil Fì al-Tārīkh. (Beirut: Dār alKutub al-'Ilmiyyah,1987).

${ }^{3}$ Ismā̄īl Ibn ${ }^{\mathrm{c} A m r u ̄ ~ I b n ~ K a t h i ̄ r, ~ a l-B i d a ̄ y a h ~ W a ~ a l-N i h a ̄ y a h ~(H i j r: ~ H i j r ~ L i ~ a l-T ̣ i b a ̄ ' a h ~ W a ~}$ al-Nashr Wa al-Tawzī' ${ }^{\mathrm{c}}$ Wa al-I'lān, 1997)

${ }^{4}$ Ibn Khaldūn, Diwān al-Mubtada' Wa al-Khabar F̄̄ Tarīkh al-'Arab Wa al-Barbar Wa Man 'Āṣarahum Min Dhaw̄̄ al-Sha'n al-Akbar, (Beirut: Dār al-Fikr, 2001)

${ }^{5} \mathrm{Abū} \mathrm{Nu}{ }^{\mathrm{c}}$ aym al-Asbahān̄̄, Dalā'il al-Nubuwwah, (Beirut: Dar al-Nafā'is, 1986)

${ }^{6}$ Fakhr al-Dīn al-Rāzī, I'tiqāà̃t Firaq al-Muslimīn Wa al-Mushrikīn, (Beirut: Dār alKitāb al-'Arabī, 1986)
} 
Rihlah Ibn Jubayr (1145-1217) ${ }^{1}$ or Rihlah Ibn Battutah (1304-1377), ${ }^{2}$ the Sufi metaphysical treatises of Ibn ${ }^{\mathrm{C}} \mathrm{Arabī}(\mathrm{d} .1240)^{3}$ and ${ }^{\mathrm{c}} \mathrm{Abd}$ al-Karīm alJ̄ilī (d. 1424). ${ }^{4}$ Whilst, al-Bīrūn̄̄ss F̄̄ Tahquīq Mā Li al-Hind Min Maqūlah Maqbūlah $F \bar{\imath}$ al- ${ }^{c} A q l$ Aw al-Mardhūlah is categorized as early Islamic work in social science. The reason that al-Biruni's Tahquìq Mã Li al-Hind is categorized under the non-purposive category is due to the original intention of the author, which is to unveil India to his readers. Consequently, it is included altogether in this writing many descriptions on Indian religions, customs and beliefs, namely Hinduism, Buddhism, Zoroastrianism, Magianism and others. ${ }^{5}$

\section{Conclusion}

As a conclusion, Watt was not supposed to speculate that Islamic self-sufficiency means that there is no Muslim scholarship in the comparative study of religions. This is due to the historical facts and truths of Muslim contributions to this particular discipline of study, which begun not in the last couple of decades as in Watt's claim, but from the earliest days of Islam.

It seems that Watt used circumstantial evidences for his seven examples in the Muslim-Christian Encounters: Perceptions and Misperceptions to conclude Islamic self-sufficiency that disfavours the study of other religions. What Watt should really be doing was to properly discern and deeply investigate the raison d'etre of these seven examples and to compare them with the other stands in the Muslim scholarship. It is of utmost pertinence for any scholar to avoid from making any sweeping judgments, which could result to the fallacy of hasty generalization and weak conclusion.

It is evident that many early Muslim scholars mastered different disciplines of knowledge and some of them were familiar with or addressed other religion/s in their works. Their contributions were not

\footnotetext{
${ }^{1}$ Muḥammad Ibn Aḥmad Ibn Jubayr, Rị̣lah Ibn Jubayr. (Beirut: Dār Șādir, n.d).

${ }^{2}$ Muḥammad Ibn ${ }^{c}$ Abdillah Ibn Bațutah, Riḥlah Ibn Bațtutah al-Musammāh Tuhfah al-Nužzār $F \bar{\imath}$ Gharā'ib al-Amșār Wa Ajā'ib al-Asfār. (Egypt: al-Mațbacah alAzhariyyah, 1928).

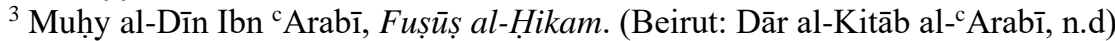

4 'Abd Al-Karīm Al-Jīlī, Al-Insān Al-Kāmil F̄̄ Ma'rifah Al-Awākhir Wa Al-Awā'ìl. (Beirut: Mu'assasah Al-Tārikh Al-'Arabī, 2000).

5 Abū Rayḥān Muḥammad ibn Aḥmad al- Bīrūn̄̄, Fī Taḥqīq Mā Li al-Hind Min Maqūlah Maqbūlah Fī al- ${ }^{c} A q l$ Aw al-Mardhūlah. (India: Maṭba ${ }^{c} a h$ Majlis Dā'irah alMaª̄rif al- 'Uthmāniyyah. 1958), 1-5.
} 
limited to certain discipline/s in which they are widely celebrated, but many of them also addressed issues related to interreligious or of other religions. Due to that, their contributions on religion/s can be traced on different disciplines and places. In the same manner, reference to religion should not only be limited to the focused, systematic and direct treatises on other religions, which called as purposive sources, but should also be made to many other non-purposive sources, which are rich with fresh information on the non-Muslim religion/s.

Therefore, this categorization or taxonomy charts the mapping of possible references for any prospective readings, researches and new findings. This categorization or taxonomy can assist one's reading towards deeper understanding on issues in Muslim scholarship in the study of other religions. Likewise, this categorization or taxonomy can also help one's research or study on the opinion of any Muslim scholars in the field of comparative religion, with no negative view that Islamic self-sufficiency entails that there is no Muslim scholarship in the comparative study of religions.

\section{References}

Al-Qur'ān al-Karīm.

Shalaby, Ahmad, Muqāranah al-Adyān: al-Yahūdiyyah. (Cairo: Maktabah al-Nahḍah al-Mișriyyah,1988).

Al-Asbahān̄̄, Abū Nu'caym, Dalā'il al-Nubuwwah. (Beirut: Dār al-Nafā'is,1986).

Al-'Asqalān̄̄, Aḥmad ibn 'Alī ibn Hajar, Fatḥ al-Bārī Bi Sharh Șaḥ̄ḥ al-Imām Muḥammad ibn Ismāàl al-Bukhārī, (Riyadh: n. pl.,2001).

Al-Bīrūn̄̄, Abū Rayḥān Muḥammad ibn Aḥmad, Fì Taḥqīq Mā Li al-Hind Min Maqūlah Maqbūlah Fì al-ciql Aw al-Mardhūlah, (India: Maṭba ${ }^{c} a h$ Majlis Dā'irah al-Ma'ārif al-'Uthmāniyyah, 1958)

Al-Dhahab̄̄, Muḥammad Husayn, Al-Isrā'ìliyyāt Fì al-Tafsīr Wa al-Hadìth, (Cairo: Maktabah Wahbah, 1990).

Al-Faruqi, Isma'il R. Christian Ethics: A Historical and Systematic Analysis of Its Dominant Ideas. (Kuala Lumpur: A.S. Noordeen, 1999).

Al-Ghazālī, Abū Hāamid, al-Munqidh Min al-Dalāl (Beirut: Dār al-Andalus,n.d)

Al-Ghazālī. Abū Ḥāmid, Ihyyā' ' Ulūm al-Dīn, (Beirut: Dār al-Macrifah,1982)

Al-Ghazālī, Muḥammad, Laysa Min al-Islām, (Cairo: Dār al-Shurūq,1998)

Al-Isfarāyīn̄̄, Abū al-Muẓaffar, al-Tabșīr Fì al-Dīn. (Cairo: al-Maktabah alAzhariyyah Li al-Turāth, 2010).

Al-Jīlī, 'Abd Al-Karīm Ibn Ibrāhim, al-Insān al-Kāmil F̄̄ Macrifah al-Awākhir Wa alAwā'il. (Beirut: Mu'assasah al-Tārīkh al-'Arabī, 2000)

Al-Khālidī, Șalāh 'Abd al-Fattāḥ. Ma ${ }^{c} a$ Qașaṣ al-Sābiqīn F̄̄ al-Qur'ān. (Damascus: Dār al-Qalam, 2007)

Al-Mas'ūdī', Abu al-Ḥasan 'Alī ibn al-Ḥusayn, Murūj al-Dhahab Wa Macādin alJawhar, (Beirut: al-Maktabah al- ${ }^{\mathrm{c}}$ Așriyyah, 2005) 
Al-Māturīdī, Abū Manșūr Muḥammad. Ta'wīlāt Ahl al-Sunnah. (Beirut: Dār al-Kutub al-'Ilmiyyah, 2005)

Al-Nawaw̄̄, Abū Zakariyyā Yaḥyā ibn Sharaf, Șaḥ̄h Muslim Bi Sharh al-Nawawī. (Beirut: Dār al-Kutub al-'Ilmiyyah, 1424H)

Al-Rāzī, Fakhr al-Dīn. I'tiqādāt Firaq al-Muslimīn Wa al-Mushrikīn. (Beirut: Dār alKitāb al-c'Arabī, 1986).

Al-Rāzī, Fakhr al-Dīn, al-Tafsīr al-Kabīr, (Beirut: Dār Iḥyā' al-Turāth al-'Arabī, 2001).

Al-Shāfiı̄̄ō, Muḥammad ibn Idrīs. al-Risālah (Beirut: Dār al-Kutub al-'Ilmiyyah, n.d.).

Al-Shahrastānī, Muhammad Ibn ${ }^{\mathrm{c}}$ Abd al-Karīm, al-Milal Wa al-Nihal, (Beirut: Dār alMacrifah, 1993).

Al-Sharqāwī, Muḥammad ' Abd Allāh, Buḥūth F̄̄ Muqāranah al-Adyān, (Cairo: Dar alFikr al-' $\left.{ }^{\mathrm{A}} \mathrm{Arab} \overline{1}, 2010\right)$.

Al-Zuhaylī, Wahbah, al-Tafsīr al-Munīr F̄̄ al- ${ }^{c}$ Aqìdah Wa al-Sharī ah Wa al-Manhaj. (Damascus: Dār al-Fikr al-Mu'āșir, 1418H)

Albayrak, Ismail. Qur'anic Narrative and Israiliyyat in Western Scholarship and in Classical Exegesis. Unpublished Doctor of Philosophy thesis. University of Leeds, 2000.

Alfred, Charlotte. (2007). Obituary | William Montgomery Watt. Edinburgh Middle $\begin{array}{lllll}\text { East } & \text { Report. } & 8 & \text { September } & 2015 .\end{array}$

http://emeronline.blogspot.my/2007/01/obituary-william-montgomerywatt.html

Aasi, Ghulam Haider. "The Qur'an and Other Religious Traditions," Hamdard Islamicus. vol. 9. no. 2. (1989).

Bassham, Greg (et. al.), Critical Thinking, (Boston: McGraw Hill Companies, 2002).

Bashir Maan and Alastair McIntosh. "The Whole House of Islam, and we Christians with them..." An interview with the "Last Orientalist." The Coracle, the Iona Community. 3:51. (2000). pp. 8-11.

Gardiner, Mark Q. and Engler, Steven. "Semantic Holism and the Insider-Outsider problem," Religious Studies, 48, (2012). pp. 239-255.

Gibbon, Edward. The History of the Decline and Fall of the Roman Empire, (Philadelphia: William Y. Birch and Abraham Small, 1805).

Hillenbrand, Carol. (2006). Professor W. Montgomery Watt: Son of the Presbyterian manse and Episcopal priest who became a leading interpreter of Islam. The Independent UK. 8 September 2015. <http://www.independent.co. uk/news/obituaries/professor-w-montgomery-watt-423394.html>

Holloway, Richard. (2006). William Montgomery Watt: A Christian scholar in search of Islamic understanding. The Guardian UK. 8 September 2015. <http://www.theguardian.com/news/2006 /nov/14/guardianobituaries.highereducation>

Ibn al-Athīr, Muḥammad Ibn Muḥammad. al-Kāmil Fī al-Tārīkh, (Beirut: Dār al-Kutub al-'Ilmiyyah,1987).

Ibn Arabī, Muḥy al-Dīn. Fuṣūṣ al-Hikam, (Beirut: Dar al-Kitāb al-'Arabī, n.d.).

Ibn Baț̣utah, Muhammad Ibn ${ }^{\mathrm{c}}$ Abd Allāh. Riḥlah Ibn Bațtutah al-Musammāh Tuhfah al-Nuzzāā $F \bar{l}$ Gharā'ib al-Amșār Wa Ajā'ib al-Asfār, (Egypt: al-Mațba ah alAzhariyyah, 1928)

Ibn Hazm, Muḥammad 'Alī Ibn Aḥmad, al-Fiṣal Fì al-Milal Wa al-Ahwā' Wa alNihal, (Beirut: Dār al-Ihyā̄' al-Turāth al-' Arab̄̄, 2002)

Ibn Jubayr, Muḥammad Ibn Aḥmad. Riḥlah Ibn Jubayr. (Beirut: Dār Șādir, n.d.). 
Ibn Kathīr, Ismā̄̄̄ll Ibn ${ }^{\mathrm{c}}$ Amrū. al-Bidāyah Wa al-Nihāyah, (Hijr: Hijr Li al-Ṭibā'ah Wa al-Nashr Wa al-Tawzī' Wa al-I'lān, 1997).

Ibn Kathīr. Tafsīr al-Qur'ān al-'스̀m, (Cairo: Muassasah Qurțūbah, 2000).

Ibn Khaldūn, 'Abd al-Raḥmān. Dīwān al-Mubtada' Wa al-Khabar F̄̄ Tārīkh al-'Arab Wa al-Barbar Wa Man 'Āṣarahum Min Dhawī al-Sha'n al-Akbar, (Beirut: Dār al-Fikr, 2001).

Ibn Taimiyyah. Muqaddimah Fī Ușūl al-Tafsīr, (Beirut: Dār Ibn Hazm, 1994).

Kamaruzzaman, Kamar Oniah. Early Muslim Scholarship in Religionswissenschaft, (Kuala Lumpur: International Institute of Islamic Thought and Civilization, 2003).

Knott, Kim. Inside, Outside and the Space in-between: Territories and Boundaries in the Study of Religion. Temenos: Nordic Journal of Comparative Religion. 44 (1). (2008). pp. 41-66.

Lawrence, Bruce. Shahrastani on the Indian Religions, (Mouton: Mouton Co. 1976).

McCutcheon, Russell. T. The Insider/Outsider Problem in the Study of Religion: A Reader. (London: Cassell, 1999).

Mez, Adam. The Renaissance of Islam. trans. by Salahuddin Khuda Bakhsh and Margoliouth, (D.S. Patna: Jubilee Printing \& Publishing House, 1937).

Muhammad Abd. Rauf. The Muslim Mind: Foundation and Early Manifestation. (Kuala Lumpur: Dewan Bahasa dan Pustaka, 1991).

Olson, Carl. Introduction. In Theory and Method in the Study of Religion: A Selection of Critical Readings. (USA: Cengage Learning, 2003).

Pembroke, Neil. Outsiders and Insiders Personal Reflections on Methodology in Studies in Religion at the University of Queensland, 1986-2010. Crossroads. 5 (2). (2011). pp. 123-126.

Sharpe, Eric John. Comparative Religion: A History, (Illinois: Open Court. 1986).

Smart, Ninian. "Study of Religion." Encyclopedia Britannica. Retrieved September 18, 2006, via Encyclopedia Britannica 2006 Ultimate Reference Suite DVD.

The American Heritage Dictionary of English Language, (Boston: Houghton Mifflin, 1992).

Waardenburg, Jacques. (ed.) Muslim Perceptions of Other Religions: A Historical Survey. (Oxford: Oxford University Press,1999).

Watt, William MontgomeryThe Faith and Practice of al-Ghazali. (London: George Allen and Unwin Ltd., 1952).

Watt, William Montgomery. Muslim Intellectual Al-Ghazali (Edinburgh: Edinburgh University Press, 1963).

Watt, William Montgomery. Early Islam, (Edinburgh: Edinburgh University Press, 1991).

Watt, William Montgomery. Muslim-Christian Encounters: Perceptions and Misperceptions. (London and New York: Routledge, 1991). 